\title{
Article
}

\section{Can Computers Automate Welfare?}

Norwegian Efforts to Make Welfare Policy More Effective

\author{
Karl Kristian Larsson \\ OsloMet - Oslo Metropolitan University
}

Marit Haldar

OsloMet - Oslo Metropolitan University

\begin{abstract}
Information-driven automated systems that deliver services proactively to citizens in need are heralded as the next level of digital government. There is, however, concern that such systems make welfare services less accessible to some citizens. This study uses the case of Norway's child benefit system to discuss the general obstacles to having welfare policies implemented by proactive digital systems. Norway's automated child benefit system uses data from Norway's national resident register to award this benefit to eligible parents whom the system identifies. As such, it is representative of many government systems that use registry data to perform tasks previously done by caseworkers. While the eligibility rules for child benefits are simple, and the register has sufficient data to automate most cases, many parents are not awarded the benefit automatically. This article argues that when developing automated digital services, public administrators are faced with a trilemma. Ideally, proactive automation should be (1) precise in its delivery, (2) inclusive of all citizens, and (3) still support welfare-oriented policies that are independent of the requirements of the digital system. However, limitations with each requirement prevent all three from being realized at the same time. Only two can be simultaneously realized: a public administrator must decide which of them to forego. Consequently, automated services cannot meet all the expectations of policymakers regarding the benefits of digital government. Instead, governments need to find ways of utilizing the benefits of public digitalisation without infringing on citizens' right to be treated equally and fairly by the government.
\end{abstract}

\section{Keywords}

administrative exclusion, automated decision-making, digital citizenship, digital divide, egovernment

Proponents of increased government digitalization see it as an opportunity to create a new paradigm for delivering and creating public services (Katsonis and 
Botros 2015, Barcevičius et al. 2019). By using the data available in governmental databases, or so the argument goes, public administrators can create systems for service delivery that are context-sensitive and oriented toward citizens' needs (Janowski 2015, Dunleavy et al. 2006). One of the more ambitious innovations has been the use of governmental registry data to proactively address the needs of citizens (Dornan and Hudson 2003). As described by Scholta et al. (2019), the most advanced forms of welfare automation replace the citizen as the initiator of service delivery. No forms are needed as the government uses data from their own registries to provide services when they learn of a citizen's need and eligibility. Accordingly, no human bureaucrat is needed as the digital system rules on all cases, ostensibly without prejudice or discrimination.

This approach to the provision of welfare services is defined by its proactivity. As such, this type of automation should not be confused with the more limited automation found in many computerized systems. All digital systems have some level of automation, although the extent will depend on the design of the system. A particularly controversial use of automation in public services has been the rise of automated decision-making, which takes power away from human bureaucrats and removes their discretionary power in providing services to citizens (Wihlborg, Larsson, and Hedström 2016, Bovens and Zouridis 2002). However, an automated and proactive system automates almost every step between a citizen being eligible for a public benefit and when they are awarded it. The argument for full proactive automation goes as follows: Unlike other forms of automation used to increase cost-effectiveness and quality of administration, proactive automated welfare services transfer the benefits to the citizens, who no longer have to spend time understanding their rights and going through the application process. Furthermore, while introducing or changing welfare policies usually requires substantial changes to the organization and administration of public agencies, a policy that can be delivered through full digital automation can flow almost directly from the lawmaker's pen to implementation, only pausing to be programmed by the IT developers.

So far, delivering welfare services proactively through digital systems has been discussed more by scholars (Scholta et al. 2019, Scholta and Lindgren 2019, Sirendi et al. 2018) and by public administration reformers (Larsen 2018), than it has been realized in practice. There are, however, a few examples of large-scale public programs that are being delivered by proactive automation. Two examples of such systems in Norway are the child benefits that are granted automatically to many parents and, more recently, benefits to the unemployed during the Covid-19 pandemic (Vågeng 2020, Andresen 2008). Both these systems have allowed the Norwegian government to award cash benefits to a large number of people without a need for caseworkers to decide on the cases or for citizens to understand the eligibility criteria and go through the process of applying.

Automation of service delivery is thus a means for making public goods more accessible and more cost-effective to administer. Proactive automation therefore 
addresses a general concern in the implementation of any social policy: making it available to all those who are entitled to it. After all, if the benefits outlined in a social policy are not readily accessible, the policy itself is unsuccessful. In previous research, the limits to accessibility have been studied as barriers that impede citizens' ability to access public goods (Schaffer and Huang 1975, Bleiklie 1997). These barriers are usually created by the administrative demands of the organization, for instance, demands that citizens engage in time-consuming or complicated paperwork (Herd et al. 2013, Herd and Moynihan 2019).

However, while automation by the government might appear to be the solution to issues that have previously kept citizens from receiving assistance from government agencies, new problems are becoming apparent. Government databases were not created for the purpose of supporting the delivery of welfare services. The ordering of data in databases requires the implementation of information architecture. Ordering and categorizations are done for a particular purpose, which reduces their suitability for other uses (Dahlbom and Mathiassen 1993, Bowker and Star 2000). Government databases are designed to service many needs, most notably storing general data about citizens. Fulfilling these needs makes their quality and design inadequate for delivering specific public services (Peeters and Widlak 2018). Consequently, services are not properly delivered to all citizens who need them. Furthermore, even if they are delivered to a citizen, it does not necessarily mean they are delivered to the citizen's satisfaction or benefit. Digital automation also prevents human caseworkers from intervening on behalf of citizens. Previous research has shown that removing decisions from street-level bureaucrats and delegating these instead to digital systems may lead to a loss of discretionary judgment (Bovens and Zouridis 2002, Wihlborg, Larsson, and Hedström 2016). Citizens who previously benefited from discretion being exercised in their favor, may find themselves rejected when rules are administered by machine logic. These rejections are still discretional, although the judgment was made by the developers when the system was designed (Reddick 2005). In proactive automated services, the rules and data that decide whether a citizen should receive a public good are positioned at the access point. Ineligible applicants are not just rejected if they apply; they may be barred entirely from trying.

The purpose of this article is to discuss the actual implications of welfare automation and to critically assess the possibility of having welfare services that proactively allocate benefit payments and services to qualified citizens without the need for human caseworkers. An important prerequisite for welfare services is that they are socially oriented. Any digital delivery of welfare policy must therefore do so without reducing its impact on the social challenges the policy is intended to address. Most welfare policy measures are intended to increase inclusion, equality, and participation in society, and to reduce the risk of exclusion, poverty, and societal differences (Titmuss 1958, Le Grand 2018, Marshall 2006). Digital solutions must contribute to this. Our study assesses whether this is the case, and the following question is asked: 


\section{Can welfare policy be implemented by using digital systems that automatically and proactively deliver goods and services to the citizens who are entitled to them?}

From a societal and welfare perspective, the question raised in this article is important as the uncritical digitalization of public services may damage the ability of welfare organizations to support healthy and inclusive societies. In their development of welfare services, governments may turn to digital systems to provide greater value for both governmental agencies and citizens. Some consider this to be a paradigm shift in how public administrators approach the task of administering public services (Margetts and Dunleavy 2013, Persson and Goldkuhl 2010). While the administrative impact often comes to the forefront when digital government is discussed, scholars are increasingly questioning the value implications of the digitalization of government services (Bannister and Connolly 2014, Scott, DeLone, and Golden 2016). Studying the effects of digitalization on welfare that go beyond the administrative changes, helps to make visible the consequences of digitalization in the welfare state from a broader perspective.

While increases in digitalization are taking place in most modern welfare states, the illustrative case used in this article is from Norway. The Norwegian government has prioritized the digitalization of its public services (Ministry of Local Government and Modernisation 2019), but it is representative of an overall trend toward public digitalization in many countries. The case considered in this paper is a functioning automated welfare system within the Norwegian Labor and Welfare Administration (NAV). The child benefit system uses data from the national resident register to identify new potential recipients of the country's child benefit and then initiates a process that leads to the benefit being awarded and payment initiated. Because it uses government registry data to automate its bureaucratic processes, the system is arguably representative of proactive automated service delivery in general. As Norway's largest public agency, NAV has invested heavily in developing digital systems that provide value and benefits for both citizens and NAV itself. NAV was established between 2006 and 2011 as a merger of Norway's previously independent welfare agencies. As such, NAV's range of clients include, among others, pensioners, unemployed people, those on sick leave or disability, and, as used as a case-study in this paper, people receiving family-related benefit payments.

The rest of this paper is organized as follows. It begins with a short description of the research approach, followed by a review of previous research on digitalization and government accessibility, including automated public services. This is followed by a description of the case and how it currently and potentially delivers its services proactively. In the next section, informed by the presented case, the discussion offers a reflection on the obstacles to automated welfare systems in 
general. Finally, the article concludes, summarizes its main arguments, and offers some questions for further research.

\section{Taking Apart the Machine}

The article's contribution and reference literature are mainly within the field of public administration. This is a field that has grown to include many of the new questions and issues being generated by the increased use of digital tools in providing public services. As such, the field is less concerned with general ethical or philosophical questions regarding digital technology. Instead, it emphasizes the role, use, and consequences of transitioning to or using digital technology in administering public services and policies. There is, however, a desire for public administrators not just to administer public services but to do so in a manner that is beneficial to society (Moore 1995). However, the study of digital government is theoretically fragmented, with concepts and theories that draw on many different fields (Bannister and Connolly 2015). There is a need for a coherent theory that can provide a better understanding of the different aspects of public digitalization. While proactive automation is being pursued as a way of improving public services, there are few studies considering its impact on social policy and welfare.

This paper is conceptually oriented, and it is rooted in theories relating to public digitalization and accessibility to welfare services. As mentioned previously, its empirical foundation lies in the efforts being made by the Norwegian Labor and Welfare (NAV) administration to create more efficient administration by automating their delivery. In answering the research question, we have combined two methodical approaches. First, the study explores the illustrative case of child benefits in Norway to uncover how well the system delivers welfare services and if there are systemic barriers that prevent it being improved. This paper is based mainly on a conceptual model, but much of the knowledge about how automated welfare works in practice is based on a study done previously by one of the authors (Larsson 2021). Furthermore, we use empirical findings from previous studies in the field of public digitalization and established theory to highlight and deepen the conceptual framework. This study is thus concordant with Jaakola's (2020) definition of a conceptual model paper, the purpose of which is to present new relationships between constructs and explain why particular elements lead to certain outcomes. Further, using Jaakola's terminology, it uses proactive automation as the 'focal phenomenon' to guide the conceptualization. In the current literature, which we will come to shortly, this phenomenon is gradually being incorporated into existing theories involving public service delivery. The role of a case study is, among other things, to enable the creation of theories and concepts that will make possible further inquiries into the phenomenon (Dooley 2002). As such, the present article brings together several strains of research and shows how they are related. This is beneficial to our understanding of the automation of welfare policies and supports future inquiries into this issue. 


\section{Welfare Access Through Technology}

The late 1990s saw increased attention from both public administrators and researchers regarding the benefits of integrating government services into socalled, one-stop shops (Kubicek and Hagen 2000). With government services consolidated, citizens could more easily navigate bureaucracies and get the help they needed. As government services were also increasingly moving online, web pages were suggested as unified fronts for government agencies, offering single points of entry for citizens requiring public services (Wimmer 2002). By digitizing services and placing them online, citizens could service themselves. As an added benefit for public agencies, government web pages rarely close and require little staffing. Additionally, while public servants are often specialized in the assistance they provide, a web page can contain services and information that can be both general and specialized. By providing a single digital point of entry on the internet, citizens can easily find the 'counter' for the government agency they require services from. Beyond this initial frontpage, there is nearly no limit to how much specialized information a government agency can make available.

However, as the internet became more important in everyday life, the consequences for people not having access to it, or being unable to use it properly, became apparent (DiMaggio and Hargittai 2001, DiMaggio et al. 2004, Hargittai 2001). Many citizens struggle to use the internet when requiring public services (Madsen and Kræmmergaard 2016). While the front page of a government website can be easy to find, the citizen may not know to go there. Furthermore, even after finding the front page, citizens are then left on their own, both to find the specific information they need and to understand it. The digital development of public services thus needs to be mindful of the population's ability to use digital technology and not advance too quickly. However, while slowing down the pace of digitalization might ensure that no citizen was left with poor access to public services, developing more advanced digital services is also proposed as a solution by which to achieve the same goal (Linders, Liao, and Wang 2018). One of the solutions to these new issues was - and remains - the full automation of services. The one-stop shop was not enough; instead, governments could create 'no-stop shop' (Scholta et al. 2019). In a no-stop shop, the recipient of a public service plays no active role in acquiring it. Instead, data in national registries and databases identify the needs of the citizen and act automatically to fulfil the mandates of the welfare policies.

A conceptual description of proactive automated services has been offered by Sirendi et al. (2018). While most digital systems are highly complex, Sirendi et al. have nevertheless identified the essential components of a proactive automated system for providing public services. They visualize the system as being a chain of events and triggers. At the start of the chain, is a life event: the reason the citizen needs a public service. Examples of such life events are unemployment, sickness, the birth of a child, homelessness, and so on. These events are often within the scope of public policy. To enable proactive automation, there needs to be what Sirendi et al. call a 'proactive agent'. This is the bridge between the life event of 
the citizen and the digital solutions provided by the state. Sirendi et al. discuss several possible types of proactive agents. For instance, it could be a caseworker, or the citizen could play the role themself by actively triggering the automated service the government offers. However, from the perspective of the proactive automation described by Scholta et al. (Scholta et al. 2019), the most advanced proactive agents are found in government registries. Data collected during the pursuit of other activities, such as collecting taxes, employment records, or birth certificates, provide the government with the proactive agent it needs to trigger the delivery of services. The citizen plays no active role as the proactive agent is embedded in the already established collecting of data.

Naturally, such automated services increase governments' efficiency. They reduce the need for caseworkers as claims and applications can be handled automatically. At the same time, they also remove some of the social complications inherent in public digitalization. The risk that some citizens could be excluded due to their lack of digital competency is inconsequential if the citizens never have to interact with the digital system. The concept of a no-stop shop is a natural continuation of anticipated trends in public digitalization. As governments become richer in data about their citizens, they can put this data to use by actively employing it to carry out their public programs. For instance, when a citizen's information is entered into their medical records, it can be used to award them sick leave benefits, or if their employment status changes, it may initiate payment of unemployment benefits. When the government designs its policies, automation can give them greater flexibility in ensuring that the public goods of a policy reach those in need of them.

Automation is, in this respect, part of a larger picture as most models of the development of public digitalization predict an increasing use of data to make services more centered around the users and their needs (Janowski 2015, Margetts and Dunleavy 2013, Katsonis and Botros 2015). However, governments' development of digital services has not been straightforward, and complex rules and needs for discretionary decisions in many bureaucratic processes have proven to be obstacles when these processes are to be digitized (Henriksen 2018). Even though the needs of citizens are correctly identified by the policymakers, and the same policymakers decide on policies that will help meet those needs, they still have to be made into workable law. Finally, if digital systems are to be involved, that law has to be programmed into a form that is usable by the digital system, and the data required to run it has to be made available.

While the public administration literature recognizes the difficulties in creating automated public services, there is also growing interest in the consequences of digital innovation when it is successfully implemented. Several recent articles have raised questions about how to understand the social ramifications and the public value generated or destroyed by the digitalization of public services (Bannister and Connolly 2014, Scott, DeLone, and Golden 2016, Twizeyimana and Andersson 2019). Using the concept of public value, these articles have argued for a widening 
of how the impact of digital technology on public services is evaluated. In their view, the consequences of digital innovation in the public sector are understudied and often overlooked when considering the impact of the digital state. From this perspective, digitalized services should not be evaluated only by how user-friendly or efficient they are but also by how they impact social values, such as equality, trust, inclusion, and social justice. While a digital service may increase accessibility or be cost-effective, it can fail in creating public value if it provides services in a way that discriminates or marginalizes groups of people.

As digital technology becomes an increasing part of how governments carry out their social policies, how the government designs their systems and how citizens use them has a great impact on the quality of the service the citizens receive. Recognizing the role of digital technology in determining how well citizens can interact with the government, has led some scholars to argue that the opportunities, rights, and obligations people have in relation to the use of digital technology in society are aligned with the concepts of citizenship (Mossberger, Tolbert, and McNeal 2007, Shelley et al. 2004). These scholars equate digital rights with social rights, as discussed by Marshall (2006) in his classic work on social citizenship from 1949. In his view, a just state should extend the rights it affords its citizens not just to the civic realm but also to the social and economic realms. Marshall recognized that in order to be fully part of a free society, the citizen should not only be awarded civic and economic rights, but also have social rights to ensure their social and economic well-being. Such social rights would diminish some of the traditional class divisions and enable all classes to participate fully in society. This view of social citizenship has become an integral part of how the modern welfare state, particularly in the Nordic countries, has been developing (Esping-Andersen 1990). In most modern welfare states, the state is obliged to secure the social and economic well-being of all citizens. Since digital technology has become integral to many aspects of participation in society, digital citizenship includes the same ethical considerations (Choi, Glassman, and Cristol 2017). If public services require a citizen to have access to and skill with digital tools, the government is obliged to ensure that citizens have the opportunity to both receive and learn to use digital tools, while also providing alternatives for those who will still remain digitally excluded.

The potential applications of government data are extensive, but regardless of what the data are used for, citizens have rights. In cases involving surveillance, profiling, and targeting, citizens have the right to privacy and the right to be protected from persecution; in the case of beneficial welfare services delivered on the basis of governmental registry data, citizens have the right to be included without discrimination. This duality shows the paradox of the importance of data in modern society. On the one hand, data about a person can be an instrument of surveillance and can be used to oppress and control. On the other hand, data can provide knowledge about a person's needs, which can be used to solve those needs (Dornan and Hudson 2003). This duality in modern digital society was recognized by Jupp and Six (2001) as they divided the different consequences data could have 
for a person into three categories. In addition to data being structured and categorized to support those the authorities view as being worthy, or to punish those viewed as unworthy, Jupp and Six also recognized that people can be discriminated against if the data about them are poor or unavailable.

While governmental surveillance is not without its problems, welfare services are usually provided with the citizens' best interests in mind (Dornan and Hudson 2003). However, this does not necessarily mean that they are unaffected by Jupp and Six's (2001) three types of data categorization. While a citizen may willingly give data to the government in order to receive welfare services, the government will then decide how to use that data. The value the government places on different categories of citizens affects how the welfare services will be delivered. Previous studies have shown how welfare services, can be more beneficial those who are already well-off, rather than helping the poor who need it the most (Le Grand 2018). If data are used to automate and regulate access to welfare goods and services, digitalization could contribute to such inequality. Consequently, the risk of social policies reinforcing rather than solving social injustices is not prevented by the use of digital systems.

\section{Automation of Child Benefits in NAV}

Digitalization is a priority for the Norwegian government. Norway's ambitions for digitalization have been outlined in a series of national strategies: a strategy for digitalization in general (Ministry of Local Government and Modernisation 2016), a strategy for digitalization of the public sector (Ministry of Local Government and Modernisation 2019), and most recently, a strategy for the application of artificial intelligence (Ministry of Local Government and Modernisation 2020). While these strategies have different focuses, they are similar in that they all view digital technology as an opportunity for increased productivity and improved service quality. As outlined in the national strategies, various types of digitalization, if used correctly, can improve the life of citizens and the state's ability to govern well. Further supporting its effort for increased digitalization, the Norwegian government even created the position of a Minister of Digitalization in 2019. Internationally, Norway is rated as highly developed in terms of government digitalization (Mukhoryanova et al. 2016, United Nations 2020). As NAV is Norway's largest welfare organization - with a portfolio of services and programs relating to sick leave, unemployment, family, and pensions - it plays an important part in the government's overall digitalization effort.

While NAV has modernized and digitalized many of its functions, only one of its benefit programs is fully automated. Since 1998, NAV has had a digital system that automatically awards its child benefit to the parents of newborn children. NAV's system extracts data from the national resident register and creates a claim for the benefit when a new child is entered into the register (Andresen 2008). In the course of the automated process, NAV has built two safeguards into the system, with the potential of halting the automatic process. There is a latency 
period from the time the case is created to when the payment commences. NAV notifies the potential recipient that the benefit is about to be awarded, giving them the opportunity to inform the agency if a mistake has been made. Additionally, caseworkers from NAV routinely check newly generated claims for irregularities. If there are no objections, payments commence the month after the child is born.

The child benefit scheme was suitable for this type of digitalization because of the simplicity of its eligibility rules. To receive the benefit, a person needs only be a legal resident of Norway and the caretaking parent of a child younger than 18 . Additionally, only one parent per child can receive the benefit. However, despite the simple eligibility rules and the accessibility of the registry data, NAV has excluded many citizens from automatically receiving the benefit. Those not automatically awarded the benefit must apply using traditional forms that are handled by caseworkers. NAV's website provides the following information regarding who needs to apply manually for the benefit.

\section{[...], you must apply for child benefit if:}

The mother is not registered as living in Norway.

The child is older than six months when entitlement to child benefit starts.

The child is not born in Norway.

You may be entitled to extended child benefit.

The father is or has received child benefit for other children.

The parents have signed a written dual domicile agreement for the child and want to share the child benefit.

The child benefit is to be assessed according to the rule of the EEA agreement or other national insurance agreements.

The mother wants the father to receive the child benefit.

You are in charge of the child. In cases like this, the child will be the applicant.

You are the child's foster parent.' ${ }^{1}$

1 Collected September 17, 2020, from https://www.nav.no/en/home/benefits-and-services/ relatert-informasjon/child-benefit\#chapter-5 https://www.nav.no/en/home/benefits-andservices/relatert-informasjon/child-benefit\#chapter-5 
Each of these conditions is in some way related to the eligibility rules. For instance, an applicant must apply manually if the parent is not registered as living in Norway or if the child was not born in Norway, situations common to many foreign workers. Another situation is when there is uncertainty regarding which of the parents is to receive the benefit. Single parents can receive an extended benefit and are also not covered by the automation. Additionally, if the father has one or more children from previous relationships, he is also excluded from being automatically awarded the benefit. In most of these instances, the necessary data are available in the national resident register, although uncertainties in whether applicants in these categories are eligible for the benefit prevent the payment from being initiated automatically. Overall, the time window for automatically receiving the benefit is narrow. While a child can be entered into the register at any time, the system is only triggered if the entry is made within six months of birth, and even then, there are, as shown above, other criteria that could stop an automatic payment.

Changes in society have, in some ways, caught up with the automated child benefit system. When it was first developed, a lower percentage of recipients were in one of the excluded categories described. In particular, an increase in foreign workers has resulted in a smaller proportion of eligible citizens receiving the benefit through the automated system. Citizens of countries covered by the European Union's regulations can claim benefits in Norway as residents. However, these residents often find themselves in one of the excluded categories. They form a substantial group who are not covered by the automated awarding of the benefit. While the law has remained largely the same, changes in society have made the digital system delivering it less effective. However, it does not necessarily have to be this way. As laws can be changed to reflect developments in society, they can also be changed to enable new uses of digital technology or to overcome new barriers to the use of digital technology. Scholars recognize that using digital technology to make legal decisions is a two-way relationship. For instance, while computers can be programmed to make decisions according to the law, the laws can also be rewritten to be more easily programmable (Schartum 2010).

A recent study on NAV's child benefit case handling system gives an indication of the size of the group not covered by automation (Larsson 2021). The study shows that in 2019, a total of 36,583 people received the child benefit as a result of being identified by the automated system. In comparison, 16,840 people were awarded it after applying manually. In percentage terms, $31.5 \%$ of all recipients were awarded the benefit by applying manually.

\section{The Automation Trilemma}

The exclusionary practices of NAV's automatic system support previous studies' findings that automated systems may be of lesser benefit to atypical citizens (Wihlborg, Larsson, and Hedström 2016, Lindgren et al. 2019). Previous scholars have discussed the role of the government in defining what is 'normal'. 
Classification, ordering and registration are all tools used by the government in the act of governing (Foucault 1980). Old manuscripts, like the $11^{\text {th }}$ century British Doomsday Book, show how authorities surveyed and registered their populations well before the establishment of modern states. However, the introduction of digital systems has given new weight to how governments conduct their surveys and registrations (Peeters and Widlak 2018). The information that governments can now survey with ease and certainty makes for more reliable data, which again, can be used in automation. However, many people live in conditions of uncertainty and precariousness, outside the norms that society deems desirable, but nevertheless pushed there by social and labor politics (Standing 2011, Della Porta et al. 2016). Uncertainty is hard to categorize and creates poor data for digital systems.

The child benefit program is intended to alleviate some of the economic hardships of providing for children, and while it is a universal benefit, it is economically more significant for families with a lower income (Epland and Kirkeberg 2016). The automation of the program, however, works best for parents who are established residents of Norway and who live in traditional family units. For the sake of precision and to avoid issuing erroneous payments, residents with a weaker residential connection to Norway and people living outside the typical family unit have a higher likelihood of not being awarded the benefit automatically. As long as they have to apply manually, the application process is not equal or inclusive. Although the system is automated, it is only automated for some. The no-stop shop is in reality a some-stop shop. Hypothetically, if the laws were different and more in line with the limitations of the digital system, more cases could be awarded automatically. However, this would also entail a loss of benefits for many people. Furthermore, NAV could be less restrictive when it automatically initiates payment, although this could lead to more citizens having to return payments they had been given by mistake.

Returning to the research question, is it possible for welfare policies to be implemented using digital systems that automatically and proactively deliver goods and services to the citizens who are entitled to them? Considering the options and the limitations described above, the answer seems to be 'no.' The case study has shown that automated systems cannot implement welfare policy proactively and automatically to eligible recipients only. The most obvious conflict lies in whether the automation is either precise or encompasses all citizens. If more eligible people are covered, it also means that more erroneous payments will be made. However, these two criteria can still be covered if the social policy is limited to what is programable. However, such a path would limit social policy to the requirements of digitalization (see Figure 1). As the case has shown, automation can only realize two goals. Prioritizing two of the goals will weaken the third. In other words, there is a trilemma that prevents governmental agencies from fully automating their services. The choices are between (1) creating a service that is completely inclusive, (2) achieving a high level of precision that rarely awards the service erroneously, 
and (3) an independent welfare policy that is not adapted to suit the requirements of digital implementation.

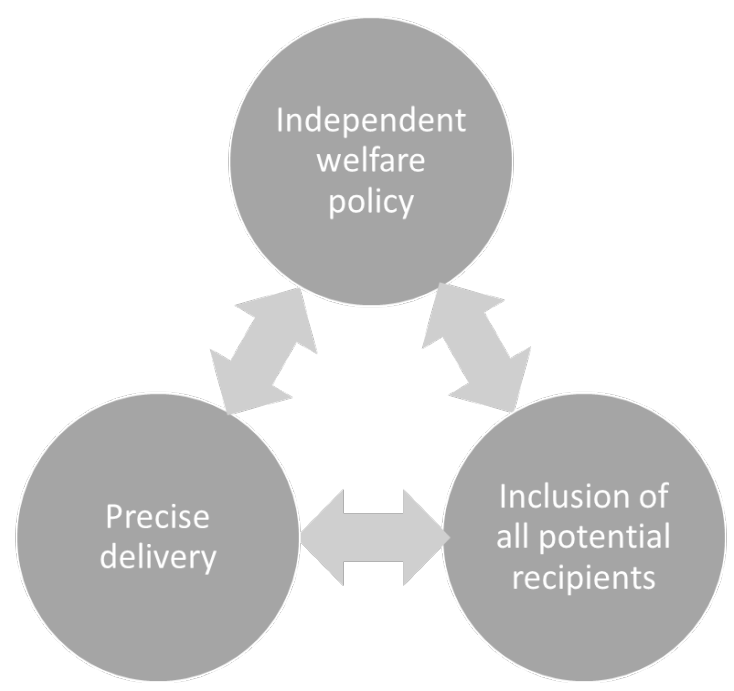

Figure 1: The Automation Trilemma

In the context of the illustrative case, the digital system is designed to meet two of the goals above. First, by excluding several groups, NAV has decided to prioritize precision and the avoidance of making erroneous payments. Second, Norwegian lawmakers did not design the child benefits law with full digitalization in mind; as such, the welfare policy is independent of the needs of digitalization. For that reason, the automated service is exclusive. Not all groups covered by the child benefit policy are included in the automated system because the risk of its making errors is too high. These groups are still eligible and can apply manually. Overall, these applicants wait longer to receive the benefit, and often have to apply multiple times to prove their eligibility before being awarded the benefit (Larsson 2021).

In theory, NAV could have made different choices. With the support of lawmakers, the framing of the eligibility rules for the benefit could be made to circumvent international obligations. Norwegian lawmakers could thus have changed the legal requirement so that the child benefit legislation did not include foreign workers. This change, and others like it, could be used to remove user groups that are not covered by the automation from being covered by the child benefit program. However, doing so would make the welfare considerations of the policy secondary to its technological considerations. Consequently, the social policy would be less able to provide welfare, as citizens would be excluded for no better reason than to make the administration of the service more cost-effective. Finally, NAV could simply accept the added risk of automating payments for all 
recipients the system identifies. This would lead to more erroneous payments but would also cover all eligible citizens without challenging the integrity of the welfare policy itself. In other words, it would shift the burden from eligible citizens applying because they were not automated to ineligible citizens taking the time to correct the mistake of an erroneous endowment. In the literature on administrative burdens, the inaccessibility of a service creates additional burdens for the citizen (Herd and Moynihan 2010). When a service is awarded proactively but erroneously, ineligible citizens are burdened with the responsibility of notifying the public agency responsible and returning what was awarded to them.

Looking beyond the illustrative case, there has been little research into government automation that evaluates what choices governments make when creating digital systems to provide services proactively. In addition, such choices would be heavily dependent on what type of service is being offered proactively. When automating schemes and programs, it seems likely that governments would choose to prioritize precision. Automation is, after all, an attempt to create value by using the government's data assets; instead of risking their value by relying on poor data, governments are trying to improve their quality. For example, data the Norwegian Tax Administration collects are widely used in the delivery of other services, and in improving the quality of this registry data, the government intends to better information sharing among government agencies (Ministry of Local Government and Modernisation 2019).

In the context of the trilemma's third option - the design of welfare policy that is independent of technological considerations - there has been increasing willingness to consider changing laws in order to ensure a more easily digitized legal framework (Schartum 2016), although bearing always in mind the potential tradeoffs between an easily automated digital system and the social benefits of welfare policies (Citron 2007). In Norway, leading public administrators and business leaders have called for increasing willingness to change laws and regulations to facilitate increased digitalization and automation (NorStella 2019, Larsen 2018). While it is hard to deconstruct all the considerations that go into creating public policies, there is some evidence that changes in welfare laws are being motivated by the benefits of digital systems. In 2016, Norwegian lawmakers made changes to how the size of sickness and family-related cash benefits were calculated (Prop. 37 2016). While the statute explicitly states that the changes will not entail a lowering of benefits for citizens, it does argue its benefit in reducing discretion and enabling more digitalization. No study has been done to evaluate if these changes have affected some citizens negatively. However, the goal of reducing discretion is, in itself, noteworthy. As previous studies have shown, the discretionary power of bureaucrats is sometimes necessary to ensure the fair treatment of citizens and the successful execution of public policy (Lipsky 2010, Molander 2016, Bovens and Zouridis 2002). Consequently, discretion is not always to be avoided, but it is rather a necessity in ensuring an equality that rigid bureaucratic regulations or digital systems are unable to give. Arguing that a 
reduction in discretion will only increase quality and will not affect any citizens adversely, as the notes on the Norwegian law do, seems unduly optimistic.

Designing digital systems is meticulous work. Deciding what data to use and how to use it is at the heart of the process (Dahlbom and Mathiassen 1993). The question of which citizens to digitally include or exclude is discussed continually as digital systems continue to be developed and improved. While human bureaucrats have the ability to make case-by-case judgments, digital systems must exclude or include on a larger scale. The same is true of public policy. With some groups already at risk for being marginalized from the scope of social policies, a lack of quality data could position them at an even greater distance from public welfare.

\section{Designing Tomorrow's Public Welfare}

In this paper, we have used a case from Norway to argue that it is almost impossible to develop information-driven computer systems that deliver welfare services proactively to citizens in a manner that is in keeping with socially beneficial welfare policies. Standing in the way of the idealized digital system is a trilemma of choices. It is not possible for proactive automation to be directed to all eligible citizens, to be exclusive of ineligible citizens, and still support laws that adhere to the social requirements of welfare policies. One of these goals must be rejected when creating a digital system that delivers welfare services proactively. Nevertheless, even in the light of the issues identified, an automated system can still be an improvement relative to previous methods of delivering welfare services. To ensure that digital welfare services and policies continue to benefit society, the automation trilemma's three options need to be better understood. This article has looked at the relationship between the three options, but more academic study should be given to each of these options and the consequences when they are not prioritized in welfare automation or if there are alternative solutions that could better resolve the issues between them. With that purpose in mind, this article concludes with some suggestions for further research.

Of the three options, the question of exclusion has recently received increased attention. Since governmental data demands categorization, automation that uses this data has been shown to create unfavorable results for some citizens acquiring welfare services (Peeters and Widlak 2018, Wihlborg, Larsson, and Hedström 2016). This has also been tied to the concept of administrative burden: a field of research aiming to explore the mechanisms of how and why bureaucratic and administrative practices place burdens on those seeking public services (Herd and Moynihan 2019, 2010). As more cases become available, the relationships between automation, exclusion, and administrative burden should be further explored.

Second, while the legal requirements of government digitalization have been discussed for several decades, little attention has been paid to the consequences of adapting welfare-related social policies to suit the needs of digitalization. Previous studies on various welfare models have shown how countries have different values 
in government, causing them to pursue different policy agendas (Esping-Andersen 1990). As digital government is often framed as a new model, a more thorough exploration of the guiding values and principles of old and new models should be conducted.

Finally, early research into e-government found that people were reluctant to use online services because they did not trust their government (Reddick 2005). In the context of this study's illustrative case, the opposite is shown to be true. While some recipients are awarded the benefit automatically, with a preliminary notification, others are not. If welfare organizations allow for imprecise automation, increased trust and responsibility are placed on citizens to correct mistakes. The effects of public digitalization in terms of how far and to whom governments can extend their trust remain understudied. Usually, the question of trust between government and its citizens relates to how much influence the citizenry is given in public decision-making (Yang 2005, Migchelbrink and Van de Walle 2021). Still, many digital services provided by the government expect citizens to self-service themselves (Breit 2019). How much, then, is the citizen allowed to do without control or supervision? It seems detrimental to the trust that people place in government if they learn that the government places more trust in their digital systems than in the citizenry.

\section{Author Bios}

Karl Kristian Larsson is a political scientist, currently writing his PhD-thesis on the effects of public digitalization on welfare services. Before returning to academia, he spent a decade in the Norwegian Labour and Welfare Administration, where he worked on several IT development projects. In his research, he explores the consequences of digitization, and how it can alleviate or contribute to social exclusion and inequality. In addition to typical quantitative methods, he also uses machine learning methods such as process mining and topic modelling to make large datasets more available to analysis.

Marit Haldar is a Professor of Sociology. Important themes in her research are childhood, gender, family, technology, digitalization, social inequality, vulnerable subjects in the welfare state and health care system. Her studies of norms and cultural perceptions of the 'ordinary' and 'normal' versus the 'different' or 'deviant' have contributed to the research on and understanding of social inequality. Haldar is head of The Research Centre for Digitalization of Public Services and Citizenship (CEDIC), and the interdisciplinary research group 'Welfare Access through Technology' (WATT).

\section{Funding}

This research for this paper was co-financed by the Norwegian Labour and Welfare Administration (NAV) and the Research Council of Norway [grant number 289920] as part of the Public Sector Ph.D. scheme. 
Karl Kristian Larsson \& Marit Haldar - Can Computers Automate Welfare?

\section{Acknowledgements}

We would like to thank editor Tereza Østbø Kuldova and the journal's anonymous reviewers for their valuable and insightful comments.

\section{References}

Andresen, Herbjørn. 2008. "Systemintegrasjon I E-Forvaltningen Og Følgene for Dokumentasjon Av Systemenes Rettslige Innhold." In Elektronisk Forvaltning På Norsk: Statlig Og Kommunal Bruk Av Ikt, edited by A. Jansen, \& Schartum, D. W. Bergen: Fagbokforlaget.

Bannister, Frank, and Regina Connolly. 2014. "Ict, Public Values and Transformative Government: A Framework and Programme for Research." Government Information Quarterly 31 (1):119-128. https://doi.org/ 10.1016/j.giq.2013.06.002.

Bannister, Frank, and Regina Connolly. 2015. "The Great Theory Hunt: Does EGovernment Really Have a Problem?" Government Information Quarterly 32 (1):1-11.

Barcevičius, Egidijus, Guoda Cibaitè, Cristiano Codagnone, Vaida Gineikytė, Luka Klimavičiūtė, Giovanni Liva, Loreta Matulevič, Gianluca Misuraca, and Irene Vanini. 2019. "Exploring Digital Government Transformation in the Eu." Luxembourg: Joint Research Centre. https://doi.org/ $\underline{10.2760 / 17207 .}$.

Bleiklie, Ivar. 1997. Service Regimes in Public Welfare Administration. Oslo: Tano Aschehoug.

Bovens, Mark, and Stavros Zouridis. 2002. "From Street-Level to System-Level Bureaucracies: How Information and Communication Technology Is Transforming Administrative Discretion and Constitutional Control." Public administration review 62 (2):174-184. https://doi.org/ 10.1111/0033-3352.00168.

Bowker, Geoffrey C, and Susan Leigh Star. 2000. Sorting Things Out: Classification and Its Consequences. Cambridge: MIT press.

Breit, Eric. 2019. "Digitalisering." In Trygd I Aktiverings Tid, edited by Ann-Helén Bay, Aksel Hatland, Tale Hellevik and Lars Inge Terum. Oslo: Gyldendal.

Choi, Moonsun, Michael Glassman, and Dean Gristol. 2017. "What It Means to Be a Citizen in the Internet Age: Development of a Reliable and Valid Digital Citizenship Scale." Computers E education 107:100-112. https:// doi.org/10.1016/j.compedu.2017.01.002. 
Karl Kristian Larsson \& Marit Haldar - Can Computers Automate Welfare?

Citron, Danielle Keats. 2007. "Technological Due Process.” Washington University Law Review 85:1249. https://digitalcommons.law.umaryland.edu/cgi/ viewcontent.cgi? article $=1404 \&$ context $=$ fac pubs.

Dahlbom, Bo, and Lars Mathiassen. 1993. Computers in Context: The Philosophy and Practice of Systems Design. New Jersey: Blackwell Publishers, Inc.

Della Porta, Donatella, Tïna Silvasti, Sakari Hänninen, and Martti Siisiäinen. 2016. The New Social Division: Making and Unmaking Precariousness. London: Palgrave Macmillan.

DiMaggio, Paul, and Eszter Hargittai. 2001. "From the 'Digital Divide'to 'Digital Inequality': Studying Internet Use as Penetration Increases." Working paper \#15. https://culturalpolicy.princeton.edu/sites/culturalpolicy/files/ wp 15 dimaggio hargittai.pdf.

DiMaggio, Paul, Eszter Hargittai, Coral Celeste, and Steven Shafer. 2004. "Digital Inequality: From Unequal Access to Differentiated Use.” In Social Inequality, edited by K Neckerman, 355-400. New York: Russell Sage Foundation.

Dooley, Larry M. 2002. "Case Study Research and Theory Building." Advances in developing human resources 4 (3):335-354.

Dornan, Paul, and John Hudson. 2003. "Welfare Governance in the Surveillance Society: A Positive-Realistic Cybercriticalist View." Social Policy \& Administration 37 (5):468-482.

Dunleavy, Patrick, Helen Margetts, Simon Bastow, and Jane Tinkler. 2006. "New Public Management Is Dead - Long Live Digital-Era Governance." Journal of public administration research and theory 16 (3):467-494. https:// doi.org/10.1093/jopart/mui057.

Epland, Jon, and Mads Ivar Kirkeberg. 2016. "Barnefamilienes Inntekter, Formue og Gjeld 2004-2014” In Oslo: Statistisk sentralbyrå.

Esping-Andersen, Gosta. 1990. The Three Worlds of Welfare Capitalism. Princeton, New Jersey: Princeton University Press.

Foucault, Michel. 1980. Power/Knowledge: Selected Interviewes and Other Writings, 1972-1977. New York: Pantheon Books.

Hargittai, Eszter. 2001. "Second-Level Digital Divide: Mapping Differences in People's Online Skills." First Monday 7 (4). https://firstmonday.org/ojs/ index.php/fm/issue/view/144.

Henriksen, Helle Zinner. 2018. "One Step Forward and Two Steps Back: EGovernment Policies in Practice." In Policy Analytics, Modelling, and 
Karl Kristian Larsson \& Marit Haldar - Can Computers Automate Welfare?

Informatics, edited by J Gil-Garcia, T. Pardo and L Luna-Reyes, 79-97. Springer.

Herd, Pamela, Thomas DeLeire, Hope Harvey, and Donald P Moynihan. 2013.

"Shifting Administrative Burden to the State: The Case of Medicaid TakeUp." Public Administration Review 73 (s1): S69-S81.

Herd, Pamela, and Donald P Moynihan. 2010. "Red Tape and Democracy: How Rules Affect Citizenship Rights." The American Review of Public Administration 40 (6):654-670. https://doi.org/10.1177/0275074010366732.

Herd, Pamela, and Donald P Moynihan. 2019. Administrative Burden: Policymaking by Other Means. New York: Russell Sage Foundation.

Jaakkola, Elina. 2020. "Designing Conceptual Articles: Four Approaches." AMS Review:1-9.

Janowski, Tomasz. 2015. "Digital Government Evolution: From Transformation to Contextualization." Government Information Quarterly 32 (3):221- 236. https://doi.org/10.1016/J.GIQ.2015.07.001.

Jupp, Ben, and Perri Six. 2001. Divided by Information?: The" Digital Divide" and the Implications of the New Meritocracy. Vol. 29: Demos.

Katsonis, Maria, and Andrew Botros. 2015. "Digital Government: A Primer and Professional Perspectives." Australian Fournal of Public Administration 74 (1):42-52. https://doi.org/10.1111/1467-8500.12144.

Kubicek, Herbert, and Martin Hagen. 2000. "One Stop Government in Europe: An Overview." In One-Stop Government in Europe. Results from 11 National Surveys, edited by Herbert Kubicek and Martin Hagen, 1-36. Bremen: University of Bremen.

Larsen, Torbjørn. 2018. Livet Er En Strøm Av Hendelser. MEMU. https:// memu.no/innspill/livet-er-en-strom-av-hendelser.

Larsson, Karl Kristian. 2021. "Digitization or Equality: When Government Automation Covers Some, but Not All Citizens." Government Information Quarterly 38 (1):101547. https://doi.org/10.1016/j.giq.2020.101547.

Le Grand, Julian. 2018. The Strategy of Equality: Redistribution and the Social Services. London: Routledge.

Linders, Dennis, Calvin Zhou-Peng Liao, and Cheng-Ming Wang. 2018.

"Proactive E-Governance: Flipping the Service Delivery Model from Pull to Push in Taiwan." Government Information Quarterly 35 (4): S68-S76. 
Karl Kristian Larsson \& Marit Haldar - Can Computers Automate Welfare?

Lindgren, Ida, Christian Østergaard Madsen, Sara Hofmann, and Ulf Melin. 2019. "Close Encounters of the Digital Kind: A Research Agenda for the Digitalization of Public Services." Government Information Quarterly 36 (3):427-436. https://doi.org/10.1016/j.giq.2019.03.002.

Lipsky, Michael. 2010. Street-Level Bureaucracy: Dilemmas of the Individual in Public Service. New York: Russell Sage Foundation.

Madsen, Christian Østergaard, and Pernille Kræmmergaard. 2016. "Warm Experts in the Age of Mandatory E-Government: Interaction among Danish Single Parents Regarding Online Application for Public Benefits." Electronic Fournal of E-government 14 (1). http://www.ejeg.com/issue/ download.html?idArticle $=447$.

Margetts, Helen, and Patrick Dunleavy. 2013. "The Second Wave of Digital-Era Governance: A Quasi-Paradigm for Government on the Web." Philosophical Transactions of the Royal Society A: Mathematical, Physical and Engineering Sciences 371 (1987):20120382. https://doi.org/10.1098/ rsta.2012.0382.

Marshall, Thomas H. 2006. "Citizenship and Social Class." In The Welfare State Reader, edited by C. Pierson, \& Castles, F. G., 30-39. Cambridge: Polity

Migchelbrink, Koen, and Steven Van de Walle. 2021. "A Systematic Review of the Literature on Determinants of Public Managers' Attitudes toward Public Participation." Local Government Studies:1-22.

Ministry of Local Government and Modernisation. 2016. "Digital Agenda for Norge." https://www.regjeringen.no/en/dokumenter/digital-agenda-fornorway-in-brief/id2499897.

Ministry of Local Government and Modernisation. 2019. "One Digital Public Sector: Digital Strategy for the Public Sector 2019-2025." https:// www.regjeringen.no/en/dokumenter/one-digital-public-sector/ id2653874.

Ministry of Local Government and Modernisation. 2020. "Nasjonal Strategi for Kunstig Intelligens." edited by Kommunal- og moderniseringsdepartementet. https://www.regjeringen.no/no/ dokumenter/nasjonal-strategi-for-kunstig-intelligens/id2685594/? $\mathrm{ch}=1$.

Molander, Anders. 2016. Discretion in the Welfare State: Social Rights and Professional Fudgment. Vol. vol. 129, Routledge Advances in European Politics. London: Routledge.

Moore, Mark Harrison. 1995. Creating Public Value: Strategic Management in Government. Cambridge: Harvard university press. 
Karl Kristian Larsson $\&$ Marit Haldar - Can Computers Automate Welfare?

Mossberger, Karen, Caroline J Tolbert, and Ramona S McNeal. 2007. Digital Citizenship: The Internet, Society, and Participation. Cambridge: MIT Press.

Mukhoryanova, Oksana A, Irina V Novikova, Slavko B Rudich, and Elena V Bogushevich. 2016. "E-Government in the Western European Countries, Asia and in the USA." Indian Fournal of Science and Technology 9 (16). https://doi.org/10.17485/ijst/2016/v9i16/90757.

NorStella. 2019. "Juridiske Hindre for Digitalisering." NorStella. https:// www.dataforeningen.no/wp-content/uploads/2019/11/Juridiske-hindrefor-digitalisering-V1.1.pdf.

Peeters, Rik, and Arjan Widlak. 2018. "The Digital Cage: Administrative Exclusion through Information Architecture-the Case of the Dutch Civil Registry's Master Data Management System." Government Information Quarterly 35 (2):175-183. https://doi.org/10.1016/j.giq.2018.02.003.

Persson, Anders, and Göran Goldkuhl. 2010. "Government Value ParadigmsBureaucracy, New Public Management, and E-Government." Communications of the Association for Information Systems 27 (1):4.

Prop. 37 L (2016-2017). Endringer I Folketrygdloven (Endret Fastsetting Av Grunnlaget for Sykepenger, Foreldrepenger Og Pleiepenger Mv.).

Reddick, Christopher G. 2005. "Citizen Interaction with E-Government: From the Streets to Servers?" Government Information Quarterly 22 (1):38-57. https://doi.org/10.1016/j.giq.2004.10.003.

Schaffer, Bernard B, and Wen-hsien Huang. 1975. "Distribution and the Theory of Access." Development and change 6 (2):13-36.

Schartum, Dag Wiese. 2010. "Developing E-Government Systems-Legal, Technological and Organizational Aspects." Scandinavian Studies in Law 56 56:125-147. https://www.jus.uio.no/ifp/om/organisasjon/seri/ forskning/publikasjoner/yulex/yulex 2011.pdf\#page=69.

Schartum, Dag Wiese. 2016. "Law and Algorithms in the Public Domain." Etikk $i$ praksis-Nordic Fournal of Applied Ethics (1):15-26. https://doi.org/10.5324/ eip.v10i1.1973

Scholta, Hendrik, and Ida Lindgren. 2019. "The Long and Winding Road of Digital Public Services-One Next Step: Proactivity.” ICIS.

Scholta, Hendrik, Willem Mertens, Marek Kowalkiewicz, and Jörg Becker. 2019. "From One-Stop Shop to No-Stop Shop: An E-Government Stage Model." Government Information Quarterly 36 (1):1 1-26. https://doi.org/ 10.1016/j.giq.2018.11.010. 
Karl Kristian Larsson \& Marit Haldar - Can Computers Automate Welfare?

Scott, Murray, William DeLone, and William Golden. 2016. "Measuring Egovernment Success: A Public Value Approach." European Fournal of Information Systems 25 (3):187-208. https://doi.org/10.1057/ejis.2015.11.

Shelley, Mack, Lisa Thrane, Stuart Shulman, Evette Lang, Sally Beisser, Teresa Larson, and James Mutiti. 2004. "Digital Citizenship: Parameters of the Digital Divide.” Social Science Computer Review 22 (2):256-269. https:// doi.org/10.1177\%2F0894439303262580.

Sirendi, Regina, Antonette Mendoza, Mariane Barrier, Kuldar Taveter, and Leon Sterling. 2018. "A Conceptual Framework for Effective Appropriation of Proactive Public E-Services." Proceedings of the European Conference on e-Government, ECEG.

Standing, Guy. 2011. The Precariat: The New Dangerous Class. London: Bloomsbury Academic.

Titmuss, Richard. 1958. "The Social Division of Welfare." In Essays on the Welfare State, edited by Richard Titmuss. London: Allen and Unwin.

Twizeyimana, Jean Damascene, and Annika Andersson. 2019. "The Public Value of E-Government-a Literature Review." Government information quarterly.

United Nations, Department of Economic and Social Affairs. 2020. "EGovernment Survey 2020; Digital Government in the Decade of Action for Sustainable Development." New York: United Nations. https:// publicadministration.un.org/egovkb/en-us/Reports/UN-E-GovernmentSurvey-2020.

Vågeng, Sigrunn. 2020. Den Store Stresstesten. MEMU. https://memu.no/ innspill/den-store-stresstesten.

Wihlborg, Elin, Hannu Larsson, and Karin Hedström. 2016. “'The Computer Says No!'--a Case Study on Automated Decision-Making in Public Authorities." Hawaii International Conference on System Sciences (HICSS), Koloa, HI, USA, 5-8 Jan.

Wimmer, Maria A. 2002. "A European Perspective Towards Online One-Stop Government: The Egov Project." Electronic commerce research and applications 1 (1):92-103. https://doi.org/10.1016/S1567-4223(02)00008-X.

Yang, Kaifeng. 2005. "Public Administrators' Trust in Citizens: A Missing Link in Citizen Involvement Efforts." Public administration review 65 (3):273-285. 